\title{
Gebelerin Eş Desteği Algıları ve İlişkili Faktörler
}

\section{Spouse Support Perception of Pregnants and Associeted Factors}

\author{
Zeynep Yüksekal ${ }^{1}$, Mine Yurdakul*2
}

\begin{abstract}
Objective: This study aims to evaluate the spouse support perception of the pregnant women registered to the provincial centres of Mersin, and the associated factors. Methods: This is a sectional study. It has been carried out at 22 Family Medicine Departments of the provincial centre of Mersin. 376 pregnant women were included in this study. The study data were collected by the researcher between 01.01 .2018 and 01.09.2018 using Personal Information Form, Spouse Support Scale. The normality control of the data was carried out with ShapiroWilk test. For the average scores of the spouse support scale, Student's t test was used in the comparisons of two independent groups while One-way Analysis of Variance [ANOVA] was applied in the comparisons of more than two groups. Among post-hoc tests, Tukey test was preferred. Statistical significance was accepted as 0.05 for all the analyses. Results: $27,9 \%$ of the pregnant women included in this study were between 25 and 29 while $42 \%$ were high school graduates. Concerning the family types, $87,5 \%$ of the pregnant women lived in a nuclear family while 52,4\% were married for 5 years at least. It was determined that the total average score of the Spouse Support Scale was $68.99 \pm 10.8$ and that the pregnant women included in this study had high spouse support perception. However, there were statisticalty significant differences in the total average scores of the Spouse Suppoit Scal in terms of the ages, educational levels, family types, ages of husbands, number of living children and voluntary pregnancy of the pregnant women [p $<0,05]$. Conclusion: It has been inferred that pregnant women and health care personnel who provide service to the former should have increased awareness for spouse support during pregancy. To this end, expectant fathers should be encoraged to attend to preconceptional care and prenatal care services.
\end{abstract}

Key words: Prenatal care, spouse support, pregnancy, social support

\section{ÖZET}

\begin{abstract}
Amaç: Araştırma, Mersin Merkez ilçelerine kayıtlı gebelerin, eş desteği algıları ve ilişkili faktörlerin değerlendirilmesi amacıyla yapılmıştır. Yöntem: Araştırma kesitsel tipte olup, Mersin İli Merkez ilçelerine bağlı 22 Aile Hekimliği biriminde yürütülmüştür. Çalışmaya 376 gebe dahil edilmiştir. Araştırma verileri 01.01.2018-01.08.2018 tarihleri arasında, Kişisel Bilgi Formu ve Eş Desteği Ölçeği kullanılarak toplanmıştır. Verilerin normallik kontrolü ShapiroWilk testi ile yapılmıştır. Eş desteği ölçeği puan ortalamaları için bağımsız iki gruba ait karşılaştırmalarda Student's t test, ikiden fazla gruba ait karşılaştırmalarda ise Tek Yönlü Varyans Analizi (ANOVA), post-hoc testlerden ise Tukey testi kullanılmıştır. Ölçeğin güvenirliği Cronbach's Alpha katsayıları ile bildirilmiştir. Bütün analizlerde istatistik anlamlıIık seviyesi 0.05 olarak alınmıştır. Bulgular: Gebelerin \%27,9'u 25-29 yaşları arasında ve \%42'si lise mezunudur. Gebelerin aile tipi incelendiğinde, \%87,5'inin çekirdek ailede yaşadı̆̆ı ve \%52,4'ünün en az 5 yıldır evli olduğu belirlenmiştir. Eş Desteği Ölçek toplam puan ortalamasının $68,99+10,8$ olduğu ve araştırma kapsamına alınan gebelerin eş desteği algısının yüksek olduğu belirlenmiştir. Gebelerin yaşları, öğrenim düzeyleri, aile tipleri, eşlerinin yaşları, yaşayan çocuk sayıları ve isteyerek gebe kalma durumlarına göre Eş Desteği Ölçeği toplam puan ortalamaları bakımından istatistiksel olarak anlamlı fark bulunmuştur $[p<0,05]$. Sonuç: Gebelerin ve gebelere hizmet sunan sağlık çalışanlarının, gebelikte eş desteği konusunda farkındalığının artırılması sağlanmalıdır. Gebelik öncesi danışmanlık ve doğum öncesi bakım hizmetlerine baba adaylarının katılımı desteklenmelidir.
\end{abstract}

Anahtar kelimeler: Doğum öncesi bakım, eş desteği, gebelik, sosyal destek

Received / Geliș tarihi: 15.07.2021, Accepted / Kabul tarihi: 21.09.2021

${ }^{1}$ Mersin Barbaros Aile Sağlığı Merkezi, MERSíN

${ }^{2}$ Mersin Üniversitesi Sağlık Yüksekokulu, Ebelik Anabilim Dalı, MERSiN

*Address for Correspondence / Yazışma Adresi: Mersin Üniversitesi Sağlık Yüksekokulu, Ebelik Anabilim Dalı Çiftlikköy Kampusu 33343 Yenişehir /MERSIN-TÜRKIYE, E-mail: mnyurdakul@gmail.com

Tel: +90 $3243610001 / 14240$

Yüksekal Z, Yurdakul M. Gebelerin Eş Desteği Algıları ve İlişkili Faktörler TJFMPC, 2021;15(4): 800-808.

DOI: $10.21763 / \mathrm{tjfmpc.971774}$ 


\section{GíRiș}

Gebelik, anne ve baba adayı için sevinç ve mutlulukla beklenen durum olmakla birlikte, aynı zamanda tüm aileyi etkileyen bir kriz dönemi de olabilmektedir. Anne adayının gebeliğe ve annelik rolüne adaptasyonunda yaşanabilecek güçlükler, anne ve bebek sağlığında olumsuz etkiler yaratabilmektedir. $\mathrm{Bu}$ nedenle, anne adayının gebeliğe uyumda yaşadığı problemlerle baş etmesini kolaylaştırmada, kaliteli sağlık bakımı almasının yanında yeterli sosyal destek sağlanması oldukça önemlidir.

Sosyal destek, bireyin stres verici veya çaresizlik gibi durumlarında fayda sağlamaya yönelik kendilerine en yakın kişilerden sağlanan maddi ve manevi destek olarak tanımlanmaktadır. ${ }^{1}$ Sosyal destek kaynakları aile, eş, arkadaş veya komşu olabilmektedir. Gebeyi rahatlatıcı etkisi olan sosyal desteğin, eşten gelmesinin gebeler için daha etkili olduğu bilinmektedir. ${ }^{2}$ Baba adayları eşlerine gebelikleri sürecinde farklı şekillerde destek sunmaktadır. Gebenin beslenme şeklini sağlıklı hale getirmek, ağır eşyaları kaldırmak gibi gebeye zarar verebilecek davranışları engellemek, ev işlerinde yardım etmek, sağlık ve ulaşım gibi giderler için parasal destek sağlamak, doğum öncesi izlemleri planlayıp eşlik etmek ve diğer çocukların bakımını üstlenmek eş desteği örnekleri arasında sayılabilir. ${ }^{3}$

Eş desteği, profesyonel desteğin yerini tutamamakla beraber önemli bir tamamlayıcıdır. Yüksek düzeyde eş desteği, aile bağlarının geliştirilmesini ve anne çocuk sağlığının korunmasını sağlamaktadır. ${ }^{4,5}$ Backström ve arkadaşları, bebek bekleyen çiftlerin gebelik boyunca karşılıklı iyi iletişimi sürdürmesi, anne adayının yaşadığı duyguları eşi ile paylaşmasının, bebek odasının dekorasyonu ve bebek kıyafetleri vb hazırlıkların birlikte yapılmasının ebeveyn rollerini güçlendirdiği vurgulamaktadır. ${ }^{6}$

Türkiye'de, birinci basamak sağlık kuruluşlarının yaygın ve ulaşılabilir olması doğum öncesi izlemler için kolaylık sağlamaktadır. Türkiye'de, Suriyeli mülteci göçü nedeniyle ebe ve hemşire başına düşen gebe sayısı artmaktadır. Bu artış sağlık çalışanlarının iş yükünü etkilemektedir. İzlemler sırasında gebeye ayrılan zaman kısıtlı olsa da, gebelere sosyal destek kaynaklarının kullanımı konusunda farkındalık yaratılması göz ardı edilmemesi gereken bir konudur. Ülkemizde, gebelikte sosyal destek ile ilgili çalışmalar bulunmakla birlikte gebelikte eş desteğini inceleyen sınırlı sayıda çalışma bulunmaktadır. Bu çalışma, gebelerin eş desteği algısını araştırmak ve ilişkili faktörleri belirlemek amacıyla yapılmıştır. Araştırmada elde edilen bulguların, sağlık profesyonellerinin sunacakları gebelik öncesi danışmanlık ve doğum öncesi bakımın planlamasında ve yürütülmesinde yol gösterici olması ve literatüre katkı sağlaması amaçlanmıştır.

\section{GEREÇ VE YÖNTEMLER}

\section{Araştırmanın Tipi Ve Örneklem Seçimi}

Araştırma, kesitsel tipte olup, 01.01.201801.09.2018 tarihleri arasında Mersin il merkezi sınırları içerisinde yer alan Akdeniz, Mezitli, Yenişehir ve Toroslar ilçelerlerinde Aile Sağlı̆̆ Merkezlerine (ASM) kayıtlı gebelerle yapılmıştır. Akdeniz ilçesi 5740, Mezitli ilçesi 2380, Toroslar ilçesi 4970 ve Yenişehir ilçesi 3110 olmak üzere kayıtlı toplam gebe sayısı 16200 'dür. ${ }^{7}$ Gebelere, eş desteği ölçeğini kullanmak için \%95 güven, \pm 5 yanılma payı ile ve 16200 gebe içinden en düşük örneklem büyüklüğü 376 gebe olarak hesaplanmıştır. İlçelerde bulunan toplam gebe sayısına göre ağırlıklandırma yapılarak, tabakalı örnekleme yöntemi uygulandığında her ilçe merkezinden ulaşılması gereken gebe sayısı ve örnekleme girecek birim sayısı belirlenmiştir. Araştırma, 22 Aile Hekimliği biriminde yürütülmüştür. Örnekleme girecek birim sayıs1, birimlerdeki gebelerin \% 30'una ulaşılabileceği düşünülerek, örnekleme alınacak gebe sayısıyla doğru orantılı olarak hesaplanmıştır. ${ }^{8}$ Araştırmaya, zihinsel yetersizliği olmayan, eşiyle birlikte yaşayan ve çalışmaya katılmaya gönüllü gebeler alınmıştır.

\section{Veri Toplama Araçları}

Araştırmanın verileri, Kişisel Bilgi Formu (KBF) ve Eş Desteği Ölçeği (EDÖ) kullanılarak toplanmıştır. Araştırmacılar tarafından hazırlanan, KBF'nda toplam on altı adet soru yer almaktadır.

EDÖ, Yıldırım tarafından 2004 yılında geliştirilmiştir. ${ }^{9}$ Ölçek, duygusal destek, maddi yardım - bilgi desteği, takdir etme desteği ve sosyal ilgi desteği olmak üzere dört alt boyuttan oluşmaktadır. Ölçekte duygusal destek ile ilgili dokuz madde, maddi yardım ve bilgi desteği ile ilgili yedi madde, takdir etme desteği ile ilgili sekiz madde, sosyal ilgi desteği ile ilgili üç madde olmak üzere toplam 27 madde bulunmaktadır. Ölçekten alınabilecek en yüksek puan 81 , en düşük puan ise 27'dir. Ölçekten alınan puanın yüksekliği, algılanan eş desteğinin fazla olmasını ifade etmektedir. Ölçeğin Cronbach Alpha katsayısı 0.95 ve test tekrar test güvenirlik katsayısı 0.89 olarak bulunmuştur. Çalışmamızda, ölçeğin Cronbach Alpha değeri 0.94'dur. Veriler, ASM' lerinde sözel mahremiyetin sağlandığı özel bir odada, birinci araştırmacı tarafından gebelerle yüzyüze görüşülerek toplanmıştır.

\section{Araştırmanın Etik Yönü}


Araştırmanın etik onayı, Mersin Üniversitesi Klinik Araştırmalar Etik Kurulu'ndan (23.02.20172017/46) alınmıştır. Araştırmaya başlamadan önce, Mersin Halk Sağlığ Müdürlüğü'nden izin alınmıştır (13.09.2017 - 40752009-302.08.01) ve çalışma hakkında Aile Hekimliği Birimi yöneticileri ve çalışanları bilgilendirilmiştir. Ayrıca araştırma kapsamına alınan gebelerin, araştırmanın amacı açıklandıktan sonra sözlü ve yazılı onamları alınmıştır.

Elde edilen araştırma verilerinin, katılımcıların isimlerini kullanmadan bilimsel amaçlı olarak kullanılacağı ve yayınlanacağı bireylere açıklanmış ve Helsinki Bildirgesi'ne uygun olarak sözlü ve yazılı onamları alınmıştır.

\section{Verilerin Değerlendirilmesi}

Araştırmanın tanımlayıcı istatistikleri, ortalama, standart sapma, minimum ve maksimum değerler ile ifade edilmiştir. Verilerin normallik kontrolü ShapiroWilk testi ile yapılmıştır. Bütün değişkenlerin normal dağılım gösterdiği belirlenmiştir. EDÖ puan ortalamaları için bağımsız iki gruba ait karşılaştırmalarda Student's t test, ikiden fazla gruba ait karşılaştırmalarda ise Tek Yönlü Varyans Analizi (ANOVA), post-hoc testlerden ise Tukey testi kullanılmıştır. Ölçeğin güvenirliği Cronbach's Alpha katsayıları ile bildirilmiştir. Bütün analizlerde istatistik anlamlılık seviyesi 0.05 olarak alınmıştır.

\section{BULGULAR}

Araştırma kapsamına alınan gebelerin yaş ortalamas1 30,29 $\pm 6,00$ 'dir. Gebelerin, \%42'si lise mezunu, yarısından çoğu $(62,2)$ çalışmıyor ve gelirlerinin giderlerine denk olduğu $(\% 62,8)$ belirlenmiştir. Gebelerin çoğunluğunun $(\% 87,5)$ çekirdek ailede yaşadığı ve ailedeki kişi sayısı en az 2 en çok 15 kişi olup ortalama 3,38 $\pm 1,58$ kişi olarak belirlenmiştir. Gebelerin \%52,4'ünün evlilik süresi 6 yıldan azdır. Gebelerin eşlerinin yaş ortalaması $34,81 \pm 6,80$ ve $\% 45,2$ 'sinin eğitim düzeyi ön lisans ve üstü'dür. Araştırmaya katılan gebelerin eşlerinin $\% 57,1$ 'i serbest meslek sahibidir. Gebelerin $\% 33,5$ '1 primipar, \%49,7'si 3.trimesterde ve $\% 88,6$ 'si planlanmış gebeliktir. Gebelerin tamamı en az 1 kez doğum öncesi bakım almıştır ve \%96'sının ilk izlemi 1. trimesterde yapılmıştır.

Tablo 1'de görüldüğü gibi, araştırma kapsamına alınan gebelerin EDÖ toplam puan ortalaması $68,99 \pm 10,8$ 'dir. Ölçek alt puan ortalamaları incelendiğinde, duygusal destek alt boyutunda puan ortalaması $23,41 \pm 3,93$, maddi yardım-bilgi desteği alt boyutunda puan ortalamas $18,01 \pm 2,88$, takdir etme desteği alt boyutunda puan ortalaması $20,02 \pm 3,32$ ve sosyal ilgi desteği alt boyutunda puan ortalamas $1,55 \pm 1,48^{\prime}$ dir.

Tablo 1. Gebelerin Eş Desteği Ölçek Puan Ortalamalarının Dağılımı

\begin{tabular}{|l|c|c|c|}
\hline Ölçek alt boyutları & Ort \pm S.Sapma & Min-Maks & Cronbach's Alpha \\
\hline Duygusal destek & $23,41 \pm 3,93$ & $9-27$ & 0,902 \\
\hline Maddi yardım-bilgi desteği & $18,01 \pm 2,88$ & $7-21$ & 0,795 \\
\hline Takdir etme desteği & $20,02 \pm 3,32$ & $8-24$ & 0,809 \\
\hline Sosyal ilgi desteği & $7,55 \pm 1,48$ & $3-9$ & 0,705 \\
\hline Ölçek toplam & $68,99 \pm 10,80$ & $28-81$ & 0,949 \\
\hline
\end{tabular}

Tablo 2'de gösterildiği gibi, gebelerin yaş gruplarına göre EDÖ toplam puan ortalamaları bakımından istatistiksel olarak anlamlı bir fark vardır $(\mathrm{p}<0,001)$. Bu fark; 19-24 yaş aralığındaki gebeler ile 35-39 yaş aralığındaki gebeler $(\mathrm{p}=0,027), 19-24$ yaş aralığındaki gebeler ile 40 yaş ve üstü gebeler( $\mathrm{p}<0,001), 25-29$ yaş aralığındaki gebeler ile 35-39 yaş aralığındaki gebeler $(\mathrm{p}=0,012)$, 25-29 yaş arasında olan gebeler ile 40 yaş ve üstünde olan gebeler $(\mathrm{p}<0,001), 30-34$ yaș arasında olan gebeler ile 40 yaş ve üstünde olan gebeler $(p<0,001)$ arasındadır. Gebelerin eğitim durumlarına göre EDÖ toplam puan ortalamaları incelendiğinde, ilköğretim mezunu gebelerin EDÖ toplam puan ortalamaları $65,75 \pm 12,4$, lise mezunu gebelerin EDÖ toplam puan ortalamaları $69,23 \pm 9,86$ ve önlisans ve üstü mezunu gebelerin EDÖ toplam puan ortalamaları $71,87 \pm 9,21$ olup, aralarında istatistiksel olarak anlamlı bir fark bulunmaktadır $(p<0,001) . B$ fark; ilköğretim-lise $(p=0,023)$, ilköğretim-önlisans ve üstü $(p<0,001)$ grupları arasındadır. Gebelerin çalışma durumuna göre EDÖ puan ortalamaları incelendiğinde; çalışan gebelerin EDÖ toplam puan ortalamaları $70,88 \pm 9,33$ ve çalışmayan gebelerin EDÖ toplam puan ortalamaları $67,84 \pm 11,47$ olup aralarında istatistiksel olarak anlaml 1 bir fark bulunmaktadır $(p=0,005)$. Çekirdek ailede yaşayan gebelerin EDÖ toplam puan ortalamaları $69,55 \pm 10,3$ ve geniş ailede yaşayan gebelerin EDÖ toplam puan ortalamaları $65,09 \pm 13,3$ olup, aralarında istatistiksel olarak anlamlı bir fark bulunmaktadır $(p=0,008)$. Gebelerin evlilik süresi gruplarına göre EDÖ toplam puan ortalamaları bakımından istatistiksel olarak anlamlı bir fark vardır ( $\mathrm{p}<0,001)$. Bu fark; evlilik süresi 0-5yıl ile 11-15 yıl arasında olan gebeler $(p=0,026)$, evlilik süresi $0-5$ yıl ile 15 yıl üstünde olan 
gebeler $(\mathrm{p}<0,001)$, evlilik süresi $6-10$ yıl ile 15 y1l üstünde olan gebeler $(p<0,001)$, evlilik süresi 11-15 y1l ile 15 y1l üstünde olan gebeler $(\mathrm{p}=0,028)$

arasindadir.

Tablo 2. Gebelerin Eș Desteği Ölçek Puan Ortalamalarının Tanıtıcı Bazı Özelliklere Göre Dağılımı

\begin{tabular}{|c|c|c|c|c|c|}
\hline Özellikler & $\begin{array}{c}\text { Duygusal } \\
\text { destek }\end{array}$ & $\begin{array}{l}\text { Maddi yardım ve } \\
\text { bilgi desteği }\end{array}$ & $\begin{array}{c}\text { Takdir etme } \\
\text { desteği }\end{array}$ & $\begin{array}{c}\text { Sosyal ilgi } \\
\text { desteği }\end{array}$ & $\begin{array}{c}\text { EDÖ } \\
\text { toplam }\end{array}$ \\
\hline Yaş & Ort \pm S.Sapma & Ort \pm S.Sapma & Ort \pm S.Sapma & Ort \pm S.Sapma & Ort \pm S.Sapma \\
\hline $19-24$ & $24,37 \pm 3,62$ & $18,46 \pm 2,62$ & $20,36 \pm 3,08$ & $7,84 \pm 1,39$ & $71,03 \pm 9,88$ \\
\hline $25-29$ & $24,08 \pm 3,62$ & $18,45 \pm 2,69$ & $20,74 \pm 3,11$ & $7,80 \pm 1,28$ & $71,07 \pm 9,85$ \\
\hline $30-34$ & $23,62 \pm 3,48$ & $18,25 \pm 2,42$ & $20,23 \pm 3,01$ & $7,63 \pm 1,42$ & $69,73 \pm 9,58$ \\
\hline $35-39$ & $22,31 \pm 4,19$ & $17,30 \pm 3,33$ & $19,33 \pm 3,50$ & $7,16 \pm 1,54$ & $66,10 \pm 11,77$ \\
\hline$\geq 40$ & $20,18 \pm 4,88$ & $16,05 \pm 3,54$ & $17 \pm 3,82$ & $6,36 \pm 1,84$ & $59,59 \pm 12,82$ \\
\hline p* & $<0,001$ & $<0,001$ & $<0,001$ & $<0,001$ & $<0,001$ \\
\hline \multicolumn{6}{|l|}{ Eğitim } \\
\hline İlköğretim & $22,46 \pm 4,70$ & $17,17 \pm 3,35$ & $19,09 \pm 3,69$ & $7,03 \pm 1,76$ & $65,75 \pm 12,64$ \\
\hline Lise & $23,42 \pm 3,56$ & $18,06 \pm 2,71$ & $20,09 \pm 3,05$ & $7,66 \pm 1,29$ & $69,23 \pm 9,86$ \\
\hline Önlisans ve üstü & $24,37 \pm 3,38$ & $18,78 \pm 2,36$ & $20,83 \pm 3,11$ & $7,90 \pm 1,28$ & $71,87 \pm 9,21$ \\
\hline p* & 0,002 & $<0,001$ & $<0,001$ & $<0,001$ & $<0,001$ \\
\hline \multicolumn{6}{|l|}{ Çalışma durumu } \\
\hline Çalışıyor & $23,99 \pm 3,17$ & $18,46 \pm 2,55$ & $20,62 \pm 3,04$ & $7,80 \pm 1,30$ & $70,88 \pm 9,33$ \\
\hline Çalışmıyor & $23,06 \pm 4,30$ & $17,74 \pm 3,04$ & $19,65 \pm 3,44$ & $7,39 \pm 1,56$ & $67,84 \pm 11,47$ \\
\hline p** & $\mathbf{0 , 0 1 7}$ & 0,018 & 0,006 & 0,006 & 0,005 \\
\hline \multicolumn{6}{|l|}{ Aile tipi } \\
\hline Çekirdek & $23,61 \pm 3,74$ & $18,16 \pm 2,77$ & $20,18 \pm 3,21$ & $7,60 \pm 1,39$ & $69,55 \pm 10,3$ \\
\hline Geniş & $22,06 \pm 4,92$ & $17,02 \pm 3,44$ & $18,87 \pm 3,87$ & $7,13 \pm 1,93$ & $65,09 \pm 13,3$ \\
\hline $\mathbf{p}^{* *}$ & 0,044 & 0,011 & 0,011 & 0,108 & 0,008 \\
\hline \multicolumn{6}{|l|}{ Evlilik süresi } \\
\hline $0-5$ & $24,23 \pm 3,50$ & $18,53 \pm 2,44$ & $20,49 \pm 3,01$ & $7,81 \pm 1,29$ & $71,07 \pm 9,33$ \\
\hline $6-10$ & $23,12 \pm 3,64$ & $17,94 \pm 2,85$ & $20,03 \pm 3,17$ & $7,50 \pm 1,44$ & $68,59 \pm 10,37$ \\
\hline $11-15$ & $22,26 \pm 4,34$ & $17,39 \pm 3,37$ & $19,16 \pm 3,97$ & $7,08 \pm 1,70$ & $65,89 \pm 12,66$ \\
\hline $15+$ & $19,83 \pm 5,37$ & $15,04 \pm 3,62$ & $17,25 \pm 3,88$ & $6,25 \pm 1,85$ & $58,38 \pm 13,63$ \\
\hline $\mathbf{p}^{*}$ & $<0,001$ & $<0,001$ & $<0,001$ & $<0,001$ & $<0,001$ \\
\hline Toplam & $23,41 \pm 3,93$ & $18,01 \pm 2,88$ & $20,02 \pm 3,32$ & $7,55 \pm 1,48$ & $68,99 \pm 10,80$ \\
\hline
\end{tabular}

*Tek Yönlü Varyans Analizi (ANOVA)

**Student's $t$ Test

Tablo 3'de görüldüğü gibi, gebe eşlerinin yaş gruplarına göre EDÖ toplam puan ortalamaları bakımından istatistiksel olarak anlamlı bir fark vardır $(p=0,001)$. Bu fark; eşleri 25-29 yaş ile 40 yaş ve üstünde olan gebeler( $\mathrm{p}=0,005)$, eşleri 30-34 yaş ile 40 yaş ve üstünde olan gebeler $(\mathrm{p}=0,042)$, eşleri 35-39yaş ile 40 yaş ve üstünde olan gebeler $(\mathrm{p}=0,042)$ arasındadır. Eşlerinin öğrenim durumlarına göre, gebelerin EDÖ toplam puan ortalamaları incelendiğinde, eşi ilköğretim mezunu olan gebelerin toplam puan ortalamaları $67,38 \pm 11,52$, lise mezunu eşi olan gebelerin toplam puan ortalamaları $68,09 \pm 11,43$ ve önlisans ve üstü mezunu eşi olan gebelerin toplam puan ortalamaları $70,45 \pm 9,79$ olup aralarında istatistiksel olarak anlamlı bir fark bulunmamaktadır. Benzer şekilde, gebelerin eşlerinin meslek durumuna göre ölçek toplam puan ortalamaları arasında anlamlı bir fark bulunmamıştır.

Tablo 3. Eş Desteği Ölçek Puan Ortalamalarının Gebelerin Eşlerinin Tanıtıcı Özelliklerine Göre Dağılımı

\begin{tabular}{|lccccc|}
\hline $\begin{array}{l}\text { Özellikler } \\
\text { Yaş }\end{array}$ & $\begin{array}{c}\text { Duygusal } \\
\text { destek }\end{array}$ & $\begin{array}{c}\text { Maddi yardım } \\
\text { bilgi desteği }\end{array}$ & $\begin{array}{c}\text { Takdir etme } \\
\text { desteği }\end{array}$ & $\begin{array}{c}\text { Sosyal ilgi } \\
\text { desteği }\end{array}$ & $\begin{array}{c}\text { EDÖ } \\
\text { toplam }\end{array}$ \\
$19-24$ & $24,85 \pm 2,21$ & $18,80 \pm 1,40$ & $20,70 \pm 1,98$ & $7,75 \pm 1,07$ & $72,10 \pm 5,30$ \\
$25-29$ & $24,50 \pm 3,98$ & $18,70 \pm 2,92$ & $20,44 \pm 3,42$ & $8 \pm 1,51$ & $71,64 \pm 11,18$ \\
$30-34$ & $23,74 \pm 3,72$ & $18,26 \pm 2,63$ & $20,37 \pm 3,05$ & $7,74 \pm 1,29$ & $70,11 \pm 9,81$ \\
$35-39$ & $23,52 \pm 3,85$ & $18,12 \pm 2,88$ & $20,33 \pm 3,50$ & $7,58 \pm 1,58$ & $69,56 \pm 11,19$ \\
$\geq 40$ & $22,08 \pm 4,19$ & $17,11 \pm 3,19$ & $18,96 \pm 3,48$ & $7 \pm 1,53$ & $65,15 \pm 11,42$ \\
p* $^{*}$ & $\mathbf{0 , 0 0 1}$ & $\mathbf{0 , 0 0 4}$ & $\mathbf{0 , 0 0 7}$ & $\mathbf{0 , 0 0 1}$ & $\mathbf{0 , 0 0 1}$
\end{tabular}




\begin{tabular}{|c|c|c|c|c|c|}
\hline \multicolumn{6}{|l|}{ Eğitim } \\
\hline İlköğretim & $22,99 \pm 4,41$ & $17,67 \pm 2,96$ & $19,56 \pm 3,39$ & $7,16 \pm 1,69$ & $67,38 \pm 11,52$ \\
\hline Lise & $23,13 \pm 4,11$ & $17,77 \pm 0,03$ & $19,66 \pm 3,54$ & $7,53 \pm 1,49$ & $68,09 \pm 11,43$ \\
\hline Ön lisans ve üstü & $23,84 \pm 3,51$ & $18,36 \pm 2,70$ & $20,50 \pm 3,08$ & $7,75 \pm 1,31$ & $70,45 \pm 9,79$ \\
\hline $\mathrm{p}^{*}$ & 0,165 & 0,104 & $\mathbf{0 , 0 3 6}$ & $\mathbf{0 , 0 0 9}$ & 0,053 \\
\hline \multicolumn{6}{|l|}{ Çalışma durumu } \\
\hline Çalışan & $23,33 \pm 0,58$ & $17,67 \pm 2,31$ & $18,67 \pm 3,06$ & $7,33 \pm 0,58$ & $67 \pm 5,29$ \\
\hline İşsiz & $23,42 \pm 3,95$ & $18,02 \pm 2,89$ & $20,03 \pm 3,33$ & $7,55 \pm 1,48$ & $69,01 \pm 10,83$ \\
\hline$p^{* *}$ & 0,971 & 0,834 & 0,481 & 0,803 & 0,749 \\
\hline \multicolumn{6}{|l|}{$\begin{array}{l}\text { Meslek } \\
\text { (Çalıssanların } \\
\text { içinde) }\end{array}$} \\
\hline Memur & $24 \pm 3,23$ & $18,46 \pm 2,54$ & $20,57 \pm 3,04$ & $7,80 \pm 1,39$ & $70,83 \pm 9,30$ \\
\hline İşçi & $23,75 \pm 40$ & $18,22 \pm 3,02$ & $20,19 \pm 3,28$ & $7,64 \pm 1,50$ & $69,81 \pm 11,01$ \\
\hline Serbest meslek & $23,09 \pm 4,11$ & $17,79 \pm 2,92$ & $19,79 \pm 3,42$ & $7,43 \pm 1,50$ & $68,09 \pm 11,16$ \\
\hline p* & 0,162 & 0,175 & 0,207 & 0,157 & 0,137 \\
\hline
\end{tabular}

Tablo 4'de katılımcıların, gebelik sayısı gruplarına göre ölçek toplam puan ortalamaları bakımından istatistiksel olarak anlamlı bir fark olduğu görülmektedir $(\mathrm{p}<0,001) . \quad \mathrm{Bu}$ fark; ilk gebeliği olan gebeler ile üçüncü gebeliği olan gebeler $(\mathrm{p}=0,001)$, ilk gebeliği olan gebeler ile dört ve daha fazla gebeliği olan gebeler $(p<0,001)$, ikinci gebeliği olan gebeler ile dört ve daha fazla gebeliği olan gebeler $(\mathrm{p}=0,001)$ arasındadır.

Planlı veya istenen gebeliği olan gebelerin EDÖ toplam puan ortalamaları $69,71 \pm 10,33$ ve gebeliği istemeyen gebelerin EDÖ toplam puan ortalamaları $63,37 \pm 12,72$ olup aralarında istatistiksel olarak anlaml bir fark bulunmaktadır( $(\mathrm{p}<0,001)$. Gebelerin gebelik sürelerine göre EDÖ toplam puan ortalamaları incelendiğinde; 1.trimesterde olan gebelerin EDÖ toplam puan ortalamaları $68,22 \pm 9,61$, 2.trimesterinde olan gebelerin EDÖ toplam puan ortalamaları $68,52 \pm 11,18$ ve gebeliğinin 3.trimesterinde olan gebelerin EDÖ toplam puan ortalamaları $69,55 \pm 10,85$ olup aralarında istatistiksel olarak anlamlı bir fark yoktur. Yetersiz DÖB alan gebelerin EDÖ toplam puan ortalamaları $68,94 \pm 11,28$ ve yeterli DÖB alan gebelerin EDÖ toplam puan ortalamaları $69,01 \pm 10,65$ olup aralarında istatistiksel olarak anlamlı bir fark bulunmamaktadır.

Tablo 4. Gebelerin EDÖ Puan Ortalamalarının Doğurganlık Özellikleri ve Doğum Öncesi Bakım Alma Durumlarına Göre Dağılımı

\begin{tabular}{|c|c|c|c|c|c|}
\hline $\begin{array}{l}\text { Tanitıcı } \\
\text { Özellikler }\end{array}$ & $\begin{array}{c}\text { Duygusal } \\
\text { destek }\end{array}$ & $\begin{array}{l}\text { Maddi yardım - } \\
\text { bilgi desteği }\end{array}$ & $\begin{array}{c}\text { Takdir etme } \\
\text { desteği }\end{array}$ & $\begin{array}{l}\text { Sosyal ilgi } \\
\text { desteği }\end{array}$ & EDÖ toplam \\
\hline \multicolumn{6}{|l|}{ Gebelik sayısı } \\
\hline İlk & $24,58 \pm 3,13$ & $18,76 \pm 2,35$ & $20,92 \pm 2,84$ & $7,90 \pm 1,22$ & $72,17 \pm 8,71$ \\
\hline 2 & $23,63 \pm 4,02$ & $18,26 \pm 2,88$ & $20,06 \pm 3,31$ & $7,65 \pm 1,47$ & $69,60 \pm 10,88$ \\
\hline 3 & $22,44 \pm 3,87$ & $17,43 \pm 2,87$ & $19,48 \pm 3,35$ & $7,27 \pm 1,47$ & $66,61 \pm 10,68$ \\
\hline 4 ve üstü & $21,03 \pm 4,87$ & $15,97 \pm 3,49$ & $17,97 \pm 3,86$ & $6,58 \pm 1,87$ & $61,55 \pm 13,15$ \\
\hline $\mathbf{p}^{*}$ & $<0,001$ & $<0,001$ & $<0,001$ & $<0,001$ & $<0,001$ \\
\hline \multicolumn{6}{|c|}{ Yaşayan cocuk sayısı } \\
\hline Yok & $24,32 \pm 3,57$ & $18,47 \pm 2,77$ & $20,74 \pm 2,99$ & $7,83 \pm 1,36$ & $71,35 \pm 9,94$ \\
\hline 1 & $23,23 \pm 4,18$ & $18,10 \pm 2,98$ & $19,74 \pm 3,48$ & $7,52 \pm 1,54$ & $68,59 \pm 11,29$ \\
\hline 2 & $22,28 \pm 3,67$ & $17,32 \pm 2,75$ & $19,36 \pm 3,27$ & $7,17 \pm 1,41$ & $66,13 \pm 10,26$ \\
\hline 3 ve daha fazla & $21,29 \pm 4,41$ & $16,38 \pm 2,78$ & $18,10 \pm 3,88$ & $6,76 \pm 1,79$ & $62,52 \pm 11,86$ \\
\hline p* & $<0,001$ & 0,001 & $<0,001$ & 0,001 & $<0,001$ \\
\hline \multicolumn{6}{|c|}{ Gebeliği isteme durumu } \\
\hline Evet & $23,67 \pm 3,77$ & $18,19 \pm 2,75$ & $20,23 \pm 3,23$ & $7,62 \pm 1,42$ & $69,71 \pm 10,33$ \\
\hline Hayır & $21,42 \pm 4,57$ & $16,63 \pm 3,46$ & $18,4 \pm 3,61$ & $6,93 \pm 1,72$ & $63,37 \pm 12,72$ \\
\hline$p^{* *}$ & $<0,001$ & 0,006 & 0,001 & 0,004 & $<0,001$ \\
\hline \multicolumn{6}{|c|}{ Gebelik trimesteri } \\
\hline 1. Trimester & $23,29 \pm 3,55$ & $17,86 \pm 2,65$ & $19,67 \pm 2,97$ & $7,39 \pm 1,39$ & $68,22 \pm 9,61$ \\
\hline 2. Trimester & $23,26 \pm 4,07$ & $17,91 \pm 2,91$ & $19,78 \pm 3,61$ & $7,57 \pm 1,56$ & $68,52 \pm 11,18$ \\
\hline 3. Trimester & $23,56 \pm 3,94$ & $18,13 \pm 2,93$ & $20,29 \pm 3,18$ & $7,57 \pm 1,44$ & $69,55 \pm 10,85$ \\
\hline
\end{tabular}




\begin{tabular}{|c|c|c|c|c|c|}
\hline $\mathbf{p}^{*}$ & 0,772 & 0,740 & 0,280 & 0,729 & 0,603 \\
\hline \multicolumn{6}{|c|}{ DÖB sıklığ $\mathbf{1} * * *$} \\
\hline Yeterli & $23,36 \pm 3,92$ & $18,1 \pm 2,79$ & $20,01 \pm 3,29$ & $7,54 \pm 1,43$ & $69,01 \pm 10,65$ \\
\hline Yetersiz & $23,58 \pm 3,97$ & $17,77 \pm 3,11$ & $20,02 \pm 3,44$ & $7,57 \pm 1,61$ & $68,94 \pm 11,28$ \\
\hline$p^{* *}$ & 0,637 & 0,341 & 0,987 & 0,874 & 0,957 \\
\hline
\end{tabular}

\section{TARTIŞMA}

Anne ve bebek sağlığını geliştirmeye yönelik araştırmalarda, genellikle anne adaylarının yaşadığı duygular ve deneyimler üzerinde durulmuştur. Gebelik sürecinde babalarla nasıl bir işbirliği yapılacağı daha az dikkate alınmıştır. Babaların aile sağlığını iyileştirmedeki önemli rolleri düşünüldügüünde, doğum öncesi, doğum ve doğum sonu süreçlerde annelere eş desteğinin varlığı ve niteliği göz ardı edilmeyecek kadar önemlidir. Babalar, babalık rol ve sorumluluklarını başarı ile yerine getirdiklerinde anne, bebek, aile ve toplum sağlığının geliştirilmesinde önemli katkı sağlanacaktır. Bu yaklaşım doğrultusunda gebelikte eş desteği, anne, bebek sağlığında koruyucu etkiye sahiptir. Ülkemizde yapılan çalışmaların çoğu gebelik döneminde algilanan sosyal destek üzerine olup, özel olarak gebelikte eş desteği algısını araştıran çalışmalar sınırlı sayıdadır. Metin ve Pasinlioğlu'nun ${ }^{10}$ çalışmasında olduğu gibi, sosyal destek alt boyutlarından biri olan "özel insan veya aile" alt boyutu eş desteği niteliğinde ele alınmıştır. Araştırmamızda, sadece gebelikte eş desteğinin değerlendirilmesi nedeniyle gebelikte eş desteği konusunda Türkiye'de yapılan ilk çalışmalar arasındadır. Araştırmamızda, gebelerin EDÖ puan ortalaması $68,99 \pm 10,8$ 'dir. EDÖ'den alınabilecek en yüksek puanın 81 olduğu düşünüldüğünde, araştırma kapsamına alınan gebelerin eş desteği algısının yüksek olduğu söylenebilir. Aynı şekilde EDÖ alt boyut puan ortalamalarının da yüksek puana yakın olduğu görülmektedir. Araştırmanın, şehir merkezinde yapılmış olması ve gebelerin eşlerinin eğitim düzeyinin nisbeten yüksek olmasının bu sonuç üzerinde etkili olduğu düşünülmektedir. Bu konuda yapılan araştırmalar incelendiğinde bulgularımızı destekler nitelikte, gebelerde eş ve aile desteği algısının yüksek olduğu gösteren çalışmalar ${ }^{3,10,11,12}$ olmakla birlikte, aksi yönde çalışmalarda bulunmaktadır. Örneğin, Üner'in ${ }^{13}$ çalışmasında gebelerin eşlerinden bekledikleri desteğin algıladıkları destekten fazla olduğu rapor edilmiştir.

Anne yaşının aile içi ve sosyal ilişkiler üzerine etkisi bilinmektedir. Çalışmamızda, gebe yaş gruplarına göre EDÖ toplam puan ortalamalarına bakıldığında, 19-29 yaş arası gebelerin eş desteği algısının daha yüksek olduğu görülürken, yaş ilerledikçe gebelerde eşdesteği algısının düştüğü görülmektedir. Bu durum, yaşla gebelik sayısının artmış olabileceği, gebeliğe uyum ve çocuk bakımı konusunda annelerin deneyim kazandıkları için eş desteğine daha az ihtiyaç duyabilecekleri şeklinde yorumlanabilir. Araştırma sonuçlarımızla benzerlik gösteren Ölçer ve ark. ${ }^{14}$ çalışmalarında, $18-30$ yaş grubundaki gebelerin sosyal destek puanları daha yüksek bulunmuştur. Çalışmamızda, eşlerinin yaş gruplarına göre EDÖ toplam puan ortalamaları bakımından $(p=0,001)$ aralarında istatistiksel olarak anlamlı bir fark olduğu görülmektedir. Gebelerin yaşları ve gebelerin eş desteği algıları arasındaki ilişki, eşlerinin yaşları ile gebelerin eş desteği algıları arasındaki ilişkiyle benzerlik göstermektedir. Iliyasu ve ark., ${ }^{15}$ babaların doğum öncesi, doğum ve doğum sonrası bakıma katılımının araştırıldığ altındaki babaların katılım sayısının 30 yaş üstündeki babalardan yüksek olduğu görülmüştür. $\mathrm{Bu}$ çalışmadan farklı olarak Nazari ve ark., ${ }^{16}$ gebelerin eşlerinin yaşı ve eş desteği arasında anlamlı bir ilişki bulunmadığını belirlemiştir.

Eğitim, kişinin kendini geliştirerek problem çözme becerilerini ve sosyal destek arayışını ve destek kaynaklarından yararlanma becerisini olumlu yönde etkileyebilir. Literatür incelendiğinde, bizim araştırmamızla paralellik gösteren çalışmalarda da görüldüğü gibi, gebe öğrenim düzeyi yükseldikçe gebelerin algıladıkları eş desteği de artmaktadır. ${ }^{14,17,18} \mathrm{Bu}$ çalışmalara paralel olarak Cheng ve ark. ${ }^{19}$ çalışmasında, gebe eğitimi ile eş desteği arasında pozitif bir ilişki olduğunu vurgulamaktadır. Gebelerin, öğrenim durumlarının eşlerinden algıladıkları destek için önemli bir değişken olduğu görülmektedir. Araştırmamızda, gebelerin eşlerinin öğrenim düzeyleri ile algıladıkları eş desteği arasında da benzerlik bulunmaktadır. Çiftlerin öğrenim düzeyleri yükseldikçe iletişim becerilerinin arttı̆̆ ve bunun bir sonucu olarak da gebelerin algıladı̆̆ eş desteğinin arttığı düşünülebilir. Çıldır ve ark. ${ }^{20}$ çalışmasında, baba eğitim düzeyi ile babaların gebelikte kontrollerine eşleriyle birlikte gitme konusundaki düşünceleri arasında anlamlı bir ilişki olduğunu ifade etmiştir. Benzer şekilde Cohen ve ark., ${ }^{17}$ eş eğitim düzeyi ile gebenin eş desteği algıs1 arasında paralel bir ilişki olduğunu belirtmiştir.

Eğitim düzeyi yükselen gebenin, çalışarak para kazanma ve dolayısıyla aile içi ilişsilerinde, rol ve sorumluluklarını yerine getirme, dayanışma 
ve yardımlaşma olasılığ 1 artmaktadır. Bu konuda yapılan çalışmalar incelendiğinde, kadının çalışmasının gebelikte eş desteğini artırdığ yönünde çalışmalar ${ }^{10,20}$ olmakla birlikte aksi yönde çalışma sonuçları da bulunmaktadır. Örneğin, Tadesse ve ark. $^{21}$ araştırmasında, çalışmayan gebelerin ve lohusa eşlerinin daha çok doğum öncesi bakıma ve bebek bakımına katıldığını bildirmektedir. Çalışmamızda, çalışan gebelerin eş desteği algısının yüksek olduğu görülmektedir. Bahsedilen ilişki, gebelerin eşlerinin çalışma durumu grupları arasında bulunamamıştır. Nazari ve ark., ${ }^{16}$ bizim çalışmamızla benzerlik gösteren çalışmasında, gebelerin eşlerinin meslekleri ve gebelerin eş desteği puanı arasında anlamlı bir ilişki bulunmadığını belirlemişlerdir.

Kadınların çalışma hayatına girmesi ile geniş ailelerin çekirdek aileye dönüşmesi, eşlerin rollerinde meydana gelen esneklik, çiftlerin destek becerilerini güçlendirmektedir. Çalışmalar, çekirdek ailede yaşayan gebelerin sosyal destek puanlarının yüksek olduğunu göstermektedir. ${ }^{10,22}$ Örneğin, Kanığ ve Eroğlu ${ }^{23}$ çalışmalarında çekirdek aileye sahip olan gebelerin sosyal destek puanının yüksek olduğunu belirlemiştir. Bizim çalışmamızda, literatürü destekler nitelikte çekirdek ailede yaşayan gebelerin EDÖ toplam puan ortalaması, geniş ailede yaşayan gebelerin EDÖ toplam puan ortalamasından daha yüksek olduğu bulunmuştur. Geniş ailede kişi sayısının fazla olması nedeni ile aile içi sorun ve sorumlulukların artma olasılığının gebenin yetersiz eş desteği algısına neden olabileceği düşünülebilir.

Evlilik süresi ve eş desteği arasında ilişki olduğu bilinmektedir. Evliliğin ilk yıllarında ailede yaşayan kişi sayısının ve dolayısıyla masrafların ve sorumlulukların az olması, eşlerin birbirlerini tanıması için zaman yaratabilmektedir. Araştırmamızda, gebelerin algıladıkları en yüksek eş desteğinin evliliğin ilk yıllarında olduğu ve evlilik yılı arttıkça eş desteğinin azaldığı belirlenmiştir. Bulgularımızı destekler nitelikte Metin ve Pasinlioğlu ${ }^{10}$ evlilik süresi 2 yıldan az olan gebelerin, eşlerinden aldıkları sosyal destek puanı yüksek bulunmuştur.

Gebelerin obstetrik özellikleri dolayısıyla yaşadıkları deneyimler eşlerinden beklenen desteğin düzeyini etkileyebilmektedir. Bu etkinin bilinmesi, DÖB alan gebelere verilen eğitimlerde eş desteği konusunda farkındalık oluşturması nedeniyle önem taşımaktadır. Çalışmamızda, primipar gebelerin EDÖ toplam puan ortalamalarının diğer gebelerden daha yüksek olduğu görülmektedir. Benzer çalışmalarda da ilk gebeliği olan gebelerin en yüksek sosyal destek puanına sahip oldukları ve yine bizim çalışmamıza benzer şekilde gebelik sayısı arttıkça sosyal desteğin azaldığ̀ görülmüştür. ${ }^{14,24} \mathrm{Bu}$ sonuçlar doğrultusunda ilk gebeliklerin çoğunlukla istenen, planlanan gebelik olmasının gebelerin eşlerinden daha fazla destek görmesine sebep olabileceği düşünülebilir.

Gebelik sayısıyla, eș desteği arasındaki ilişki gibi gebelerin çocuk sayıları ve algılanan eş desteği arasında da anlamlı bir ilişki bulunmuştur. Çalışmamızda, en yüksek eş desteği puanı çocuğu olmayan gebelerde görülürken çocuk sayısı arttıkça gebelerde eş desteği puanı azalmaktadır. Bu durumun oluşmasında artan çocuk sayısı ile birlikte sorumluluk artışı ve çocuklara ayrılan zamanın artması ile eşlerin birbirlerine yeterli zaman ayıramamalarının etkili olabileceği düşünülmektedir. Literatür incelendiğinde, bulgularmızı destekler şekilde gebelerin yaşayan çocuk sayısı arttıkça sosyal destek algısının düştüğü belirtilmiștir. ${ }^{12,14,19}$

İstenen bir gebelik aile için mutluluk ve gurur kaynağıdır. Baba olmanın sevincini yaşayan eş, gebenin ihtiyaçlarını belirlemek ve desteklemek için daha fazla çaba gösterebilmektedir. Literatür incelendiğinde, istenen, planlanan gebeliği olan kadınların sosyal destek puanlarının, istenmeyen gebeliği olan kadınlardan daha yüksek olduğu görülmektedir. ${ }^{12,24} \mathrm{Bu}$ sonuçlar bulgularımızı destekler niteliktedir.

DÖB, gebeleri aileleri ile birlikte ele alıp eş desteğinin önemi konusunda farkındalık yaratmak için önemli bir firsattır. Özdemir ve arkadaşları, ${ }^{24}$ DÖB arttıkça sosyal desteğin arttığını belirlemişlerdir. Benzer şekilde Forbes ve arkadaşları, ${ }^{25} 4$ ve daha fazla DÖB alan gebelerin eşlerinin DÖB'e katılımının daha yüksek olduğunu belirtmişlerdir. Literatürün aksine çalışmamızda araştırma kapsamına alınan gebelerin, Yeterli DÖB alma durumlarına göre EDÖ toplam puan ortalamaları arasında anlamlı bir fark olmadığı görülmüştür ( $p=957$ ) (Tablo 4). Bu durum doğum öncesi izlemlerin eş desteği konusunda fakındalık yaratacak nitelikte düzenlenmediği, sağlık personelinin bakım ve eğitimlere eşlerin katılımı için gebe ve eşlerini cesaretlendirmediği şeklinde yorumlanabilir.

\section{SONUC}

Çalışma grubumuzdaki gebelerin algıladıkları sosyal destek sosyo demografik özelliklerine göre farklılık göstermektedir. Çalışma sonuçlarımız, eğitim düzeyi düşük, ileri yaşta olan, geniş ailede yaşayan ve istenmeyen gebeliği olan anne adaylarının algıladıkları eş desteğinin düşük olduğunu göstermiştir. Benzer şekilde düşük eğitime sahip eşi olan ve eşi ileri yaş grubunda bulunan gebelerin de eş desteği algısının düşük 
olduğu görülmüştür. $\mathrm{Bu}$ sonuçlar doğrultusunda; DÖB planlanırken ve sunulurken risk yaklaşımı doğrultusunda bu özelliklere sahip gebelere ve eşlerine önem ve öncelik verilmesi, DÖB'ın bütüncül bir yaklaşımla planlanarak baba adaylarının dahil edilmesi, babanın kendini rahat ifade edebileceği uygun bir ortam ve zaman dilimi belirleyerek en azından son izleme davet edilerek sorularının cevaplanması ve bilgilendirilmesi önerilmektedir.

$\mathrm{Bu}$ araştırmanın direkt konusu olmamakla birlikte, çalışma grubumuzdaki gebelerin \%11,4'ünün istenmeyen gebeliği olduğu belirlenmiştir. Araştırmanın yapıldığı bölgede çalışan aile hekimi, ebe ve hemşirelerin DÖB ve doğum sonu bakım hizmetlerini planlarken aile planlaması hizmetlerine önem ve öncelik vermeleri önerilmektedir.

$\mathrm{Bu}$ araştırma 6-9 Kasım 2019 tarihleri arasında Ankara'da düzenlenen 5. Ulusal 4. Uluslararası Ebelik Kongresi'nde sözel bildiri olarak sunulmuştur.

\section{Çıkar Çatışması}

Yazarlar arasında herhangi bir çıkar çatışması bulunmamaktadır.

\section{Maddi Destek}

Çalışma için herhangi kurumdan finansal destek alınmamıștır.

\section{KAYNAKLAR}

1. Feeney BC, Collins NL. A new look at social support: A theoretical perspective on thriving through relationships. Personality and Social Psychology Review 2015;19(2):113-147.

2. Gul B, Riaz MA, Batool N, Yasmin H, Riaz M $\mathrm{N}$. Social support and health related quality of life among pregnant women. J Pak Medassoc 2018; 68(6): 872-875.

3. Sokoya M, Farotimi A, Ojewole F. Women's perception of husbands' support during pregnancy, labour and delivery. IOSR Journal of Nursing and Health Science 2014; 3(3):4550 .

4. Matseke MG, Ruiter RAC,Barylski N, Rodriguez VJ, Jones DL,Weiss SM,et al. A qualitative exploration of the meaning and understanding of male involvement in pregnancy- related care among men in Rural South Afrika. Journal of Social, Behavioral, and Health Sciences 2017;11,1:215-230.

5. Höglund B, Larsson M. Professional and social support enhances maternal wellbeing in women with intellectual disability - A Swedish interview study. Midwifery 2014; 30(11): 1118-23.

6. Bäckström C, Thorstensson S, Mårtensson LB, Grimming R, Nyblin Y, Golsäte M. To be able to support her, I must feel calmand safe': pregnant women's partners perceptions of professional support during pregnancy. BMC Pregnancy and Childbirth 2017; 17, 234.

7. Mersin İl Halk Sağlığ İstatistik Şubesi, 2016 Y1lı Gebe Tesbit Verilerinden elde edilmiştir.

8. Blanche MT, Durrheim K, Painter D. Research in Practice: Applied Methods For The Social Sciences. South Africa: UCT Press.2006.p.594.

9. Yıldırım İ.Eş destek ölçeğinin geliştirilmesi. Psikolojik Danışma ve Rehberlik Dergisi 2004; 3(22):19-25.

10. Metin A, Pasinlioğlu T. The relationship between perceived social support and prenatal attachment in pregnant women. JACSD 2016;(5):49-66.

11. Bernard O, Gibso RC, McCaw-Binns A, Reece J, Coore-Desai C,Pellington S,et al. Antenatal depressive symptoms in Jamaica associated with limited perceived partner and other social support: A Cross-Sectional study. Plos One 2018; 13(3); e0194338.

12. Yurdakul $M$, Perceived social support in pregnant adolescents in Mersin area in Turkey. Pak J Med Sci.2018; 34(1):115-120.

13. Üner R.Spousal social support fort he pregnant women recipient's ad providers'perspectives on perceived and desired social support. Master of Science in Social Psychology, Middle Esast Tecnical University 1994.p. 55.

14. Ölçer Z, Bakır N, Oskay Ü. Yüksek riskli gebelerin öz yeterlilik ve sosyal destek algıları. Anadolu Hemşirelik ve Sağlık Bilimleri Dergisi 2016;19(1):25-33.

15. Iliyasu Z, Abubakar IS, Galadanci HS, Aliyu MH. Birth preparedness, complication readiness and Fathers'Participation in maternity care in a Northern Nigerian community. African Journal of Reproductive Health 2010;14(1):21-32.

16. Nazari M, Ghasemi S, Vafaei H,Fararouei M. The perceived social support and its relationship with some of the demographic characteristics in Primigravida pregnant women. International Journal of Nursing and Midwifery 2015; 7(9);141-145.

17. Cohen K, Capponi S, Nyamukapa M, Baxter JC, Worly B. Partner involvement during pregnancy and maternal health behaviors. Matern Child Health 2016; 20:2291-2298.

18. Peter P, Mola CL, Matos M B, Coelho F M, Pinheiro K A, Silva R A, et.al. Association between perceived social support and anxiety in pregnant adolescents. Revista Brasileira de Psiquiatria 2017; 39: 21-27. 
19. Cheng ER, Rifas-Shiman SL, Perkins ME, Rich-Edwards JW, Gillman MW, Wright R,et al. The Influence of antenatal partner support on pregnancy outcomes. Journal of Women's Health.2016; 25(7); 672-679.

20. Çıldır G, Karakoç A, Karaca S. Babaların Bebek Bakımına Katılımının Değerlendirilmesi. Uluslararası Hakemli Akademik Spor Sağlık ve Tıp Bilimleri Dergisi 2014;10(4);1-15.

21. Tadesse M, Boltena AT, Asamoah B O. Husbands' partcipaton in birth preparedness and complicaton readiness and associated factors in Wolaita Sodo town, Southern Ethiopia.Afr J Prim Health Care Fam Med.2018;11,10(1): e1-e8.

22. Güngör İ. Doğum öncesi hazırlık eğitimlerinde babaların yeri ve gereksinimleri. Turkiye
Klinikleri J Obstet Womens Health Dis NursSpecial Topics.2015; 1(1): 44-51.

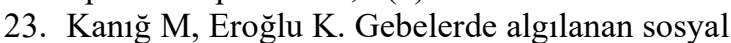
destek düzeyi ve etkileyen faktörler. Hemşirelikte Eğitim ve Araştırma Dergisi 2019;16(2):125-133

24. Özdemir F, Bodur S, Nazik E, Nazik H, Kanbur A.Hiperemezis Gravidarum tanısı alan gebelerin sosyal destek düzeyinin belirlenmesi. TAF Prev Med Bull. 2010;9(5):463-470.

25. Forbes F, Wynter K, Wade C, Zeleke BM, Fisher J. Male partner attendance at antenatal care and adherence to antenatal care guidelines: secondary analysis of 2011 Ethiopian demographic and health survey data. BMC Pregnancy and Childbirth.2018; 18(145); 2-11. 